\title{
Indigenous Entrepreneurship and Economic Development: The Moderating Effect of Post-Conflict Reconstruction in Turkana County, Kenya
}

\author{
Wambui King'ong'o, \\ School of Business and Management studies, \\ Technical University of Kenya, Nairobi, Kenya
}

Prof. Martin Ogutu,

School of Business, University of Nairobi, GPO Nairobi, Kenya

Samuel Nyandemo, PhD

School of Economics, University of Nairobi, GPO Nairobi, Kenya

Doi:10.19044/esj.2020.v16n19p520 URL:http://dx.doi.org/10.19044/esj.2020.v16n19p520

\begin{abstract}
The role of entrepreneurship in post-conflict reconstruction is largely understudied. Micro and Small livestock enterprises play an important economic and socio-cultural role amongst many Kenyan communities. The objective of this study was to establish the moderating effect of post-conflict reconstruction on the relationship between indigenous entrepreneurship and economic development in Turkana County. This study is anchored on institutional theory. Positivism and phenomenology paradigms and a cross sectional research design was adopted. The target population was all micro and small livestock enterprises that are registered members of the Livestock Marketing Association (LMA) in Turkana County; comprising of 598 livestock enterprises. A sample of 339 micro and small livestock enterprises were selected for the study using simple random sampling techniques. Data collected were analyzed using descriptive and inferential statistics like mean, standard deviation, cumulative variance, Skewness, Kurtosis, ANOVA and regression analyses. The results revealed that Post-conflict reconstruction has a significant moderating effect on the relationship between indigenous entrepreneurship and economic development in Turkana county, $(\mathrm{F}=50.22$, $\mathrm{P}=0.000$ ). The study suggests legislation of laws and policies by the national and County governments, prohibiting acquisition of small arms. Policy initiatives should support indigenous livestock enterprises for instance, creation of a suitable environment for these businesses to obtain credit. Its time both levels of governments enhance their environmental factors to lower uncertainty, raise indigenous livestock entrepreneurs to participate at the global economy, attracting FDI, private sector development, employment,
\end{abstract}


increased exports and finally spur economic development through huge investments in health, education while impacting wealth levels.

Keywords: Post-conflict Reconstruction, Indigenous Entrepreneurship, Economic Development

\section{Introduction}

In the third world nations, entrepreneurship is said to be the least studied socioeconomic phenomena. There is no qualitative data and there exists measurement difficulties on entrepreneurship in failed nations as well as post-conflict nations leading to constraints in policy and institutional reform (Lingelbach, Lynda \& Asel, 2005). The role of entrepreneurship in postconflict reconstruction is largely understudied, even when these countries are highly depleted socially, politically and economically (Tobias \& Boudreaux, 2009). According to Skran (2020), post-conflict environments are challenging for entrepreneurship, citing uncertainty, intense destruction from conflict and poor social networks. "In recent years development scholars have recognized 'institutions' (the rules of the game) as the ultimate (deep) determinants of economic development" Naude (2013:3) affecting entrepreneurship development. "Underdevelopment is not due to an insufficient supply of entrepreneurs, but due to institutional weaknesses that result in a lack of profit opportunities tied to activities that yield economic growth" (Naude, 2013:3). The view of entrepreneurship has taken a new dimension replicating institutional features of the community and therefore understood as a societal phenomenon. Institutional environment shapes entrepreneurial activities (Williams, 2019). With a conducive institutional environment which does not hinder legal entrepreneurial activities, then entrepreneurs are able to establish productive industries that are beneficial to the society (Luiz, 2010).

Post-conflict reconstruction attracts local, national, regional and international interventions (Labadie, 2008). However, the link between reconstruction efforts and economic development has not been adequately studied (Aldairany, Omar \& Quoquab, 2018; Labadie). "Institutional challenges in post-conflict economies" discourage "investors who view the financial risk to investments, lack of support and political fragmentation as barriers to investment" (Williams, 2019:4). Institutions created by postconflict reconstruction activities may therefore influence the contribution of indigenous entrepreneurship to economic development. Audretsch and Kelibach (2008) growth model measures the impact of entrepreneurship on growth, and illustrated as; $\mathrm{Y}_{\mathrm{i}}=\mathrm{K}_{\mathrm{i}} \mathrm{L}_{\mathrm{i}} \mathrm{R}_{\mathrm{i}} \mathrm{E}_{\mathrm{i}}$ where $\mathrm{Y}_{\mathrm{i}}$ is economic performance (GDP), $K_{i}$ entrepreneurship capital, $L_{i}$ labour, $R_{i}$ regional research and development intensity and $\mathrm{E}_{\mathrm{i}}$ is regions endowment in entrepreneurship capital reflecting post-conflict reconstruction institutional factors. Welfens (2013) 
growth model, illustrated as; $\mathrm{Y}=\mathrm{K}, \mathrm{L}, \mathrm{H}, \mathrm{A}, \mathrm{N}, \mathrm{T}, \Omega, \mathrm{M} / \mathrm{P}, \mathrm{E}, \phi$, representing capital, unskilled and skilled labour, technology, infrastructure capital, telecommunications, technological specialization, real money balances, energy and institutional capital respectively, reflects institutional factors as influencing long term growth. An efficient set of institutions $(\phi)$ created by post-conflict reconstruction for example the legal system could boost the overall economy. Micro and Small Enterprise (MSE) contribution to poverty reduction, wealth creation and promotion of social, economic and human development is increasingly being acknowledged in the developing countries (GoK, 2010). In Kenya Micro and Small Enterprise Act No. 55 of 2012 defines MSE's by their volume of annual sales, size of their employees and enterprise assets and financial investments (GoK: MSE Act, 2012).

Turkana is regarded as among most insecure Counties due to propinquity to Uganda, Sudan, Ethiopia and aggressive neighbouring Counties such as Baringo, Samburu, Pokot and Wajir (Department for International Development (DFID), 1999). Livestock MSE's in Turkana County are crucial to post-conflict reconstruction contributing to economic development. Postconflict reconstruction is the physical reconstruction of destroyed societies; economy, legal framework, infrastructure, rebuilding of social capital, credit provision, technical support, reinforcing conflict mitigation, eradicating war, developing or reconstituting organizational capability for managing and governance and attitudinal change encouraging globalization and diversity (Labadie, 2008 \& Bray, 2005). Post-conflict reconstruction in this study is operationalized as the physical reconstruction of destroyed societies in infrastructure and eradicating war. Economic development is the structural transformation of production from low value added and rural-based activities to more productive, higher value added activities located in urban centers (Naude, 2013). It is a multidimensional concept including eradication of income poverty, poor health and low education (Das \& Quirk, 2016; Naude, 2013; Todaro \& Smith, 2012). Economic development in this study is operationalized as reflecting social and economic progress of a region, indicated by a region's increase in citizen's quality of life, measured in education, health and income levels.

The contribution of entrepreneurship to economic development is widely argued by various scholars (Naude, 2013; Audretsch \& Kelibach, 2008). Naude (2013:1) noted that, "evidence on whether entrepreneurship matters for economic development is not straight forward; how entrepreneurship has been promoted and how it contributed to development in countries like China and the East Asian Tigers is still a matter of contention and whether and why private-sector development initiatives may be effective is not well understood". The focus of most of the reviewed studies has mostly been entrepreneurship contribution to economic development leaving a gap on 
the moderating actions of post-conflict reconstruction which is not fully conceptualized as contributing to socioeconomic development. Turkana County records large livestock numbers compared to other regions in Kenya and the presence of conflict cannot be underrated. Therefore it can be argued that to a large extent it will illustrate the contribution of micro and small livestock enterprises to economic development. The objective of this study was to establish the moderating effect of post-conflict reconstruction on the relationship between indigenous entrepreneurship among micro and small livestock enterprises and economic development in Turkana County. The study hypothesis is that, the relationship between indigenous entrepreneurship among micro and small livestock enterprises and economic development is significantly moderated by post-conflict reconstruction.

\section{Literature review}

This study was anchored on institutional theory. Institutional theory focuses on regulatory, societal as well as cultural factors (institutional environments) that enhance existence and legality of a business entity, promoting its success instead of relying on organizational micro factors (Meyer \& Rowan, 1977). Organizational micro features tend to increasingly be compatible with environmental conditions, making these firms look the same (isomorphism). Homogenization that is "isomorphism is a constraining process that forces one unit in a population to resemble other units that face the same set of environmental conditions" (DiMaggio \& Powell, 1983: 149). Firms, therefore as a matter of custom embrace ideas, rules and regulations, production processes and products that have been institutionalized (Meyer \& Rowan). This firm similarity may increase firm effectiveness, in that isomorphic firms can transact businesses easily, ability to hire quality professionals, they are esteemed and gain legitimacy and due to their legality, they attract private and government grants as well as tenders (DiMaggio \& Powell). However, institutional isomorphic activities will continue even if there is no record that micro firm efficiency is increasing. Institutional isomorphism typology occurs in three main ways (DiMaggio \& Powell). Coercive isomorphism, originate from either formal or informal political influences which may be exercised through persuasion, invitation or coercion. Firms reflect laws institutionalized and legitimized by the government. Mimetic isomorphism, is a standardized response to uncertainty.

Under conditions of uncertainty, existing firms may serve as models for best practices to start-ups. An existing organization is able to secure resources and legitimacy based on past performance records. For start-ups with no past record on performance, organizational structures adherence to institutionalized procedures may be used to legitimize the firm (DiMaggio \& Powell, 1983). Normative pressures denotes the activities of professionals, 
defining their job and work environment, for the purpose of establishing a cognitive base and legitimacy of their professional independence. North (1990) highlighted two forms of institutions that is formal and informal maintaining the importance of informal institutions than formal. "Formal institutions are the rules devised by people for example laws and regulations" written "by governments" while "informal regulations include conventions and codes of behaviour" (Knowles, 2007: 200). Informal institutions function from an individual perspective based on beliefs and language including other subconscious actions that are taken for granted or supported by the opinions of the public or forced rules and regulations (DiMaggio \& Powell, 1983; Meyer \& Rowan, 1977). Formal institutional structures are necessary for venture creation while "too many rules and procedural requirements" discourage entrepreneurs from venturing (Bruton, Ahlstrom \& Han-Lin Li, 2010: 426). Organizations should conform to institutional regulations by proving their worth and demonstrate their engagement in lawful undertakings as per the institutional framework.

Legitimacy is about institutional forces identified from economics (North, 1990), sociology (DiMaggio \& Powell, 1991, 1983), political science (Bonchek \& Shepsle, 1996) and organizational theory (Meyer \& Rowan, 1991). Institutions identify how individuals and corporations establish their place and legality through compliance to laws and standards of the institutional environment (Meyer \& Rowan, 1977). "Institutional theory is an increasingly utilized theoretical lens for entrepreneurship research" (Bruton, et al 2010: 1). It demonstrates to be a widely held theoretical underpinning in surveying far-reaching areas in diverse disciplines including organizational theory, political science and institutional economics (DiMaggio \& Powell, 1991). Formal and informal institutions are deep determinants explaining income per capita one of the measures of Human Development (Knowles, 2007). They affect the proximate determinants; including human resource, physical resource and technology, making them the causal determining factors of income per capita.

\section{Post-conflict reconstruction, indigenous entrepreneurship and economic development}

In the last five decades "growth stagnation, collapse and persistent conflict" especially among numerous African nations (Naude, 2008:3) has been experienced. Various conflicts in Africa have received national and international management attention resulting in durable peace agreements. They include independence movements against colonialism in the 20th century, 1960's Biafra wars in Nigeria, Uganda-Tanzania war of 1978-1979 and Rwanda's genocide of 1994 (Devine, 2016). There are however other violent inter-communal conflicts, particularly at the intrastate level, which do 
not receive similar attention at the national and international level, making these conflicts to persist without intervention (Devine). In Northern Kenya, including Turkana, conflict has been dismissed as just 'inter clan fighting' forgetting that all conflicts start may be between two individuals or families and escalates to higher levels (Oyugi, 2002). Turkana has the highest number of displaced persons caused by war (Ruto, Mohamud \& Masinde, 2006). However it is the least highlighted in terms of violent conflict (DFID, 1999) prompting this study.

According to O'del and Boudreaux (2004) in war torn regions, entrepreneurship is key to advancing the countries development by instituting trade both local and transnational thereby increasing creativity and wealth. Rebuilding should embrace indigenous participation and therefore reconstructive measures must be derived from the affected community (Green, 1995). This promotes the motivation to resist quick fixes provided by high investment reconstruction, which eliminates the consequential proceeds from the community. Well planned post-conflict recovery and reconstruction programs can return a conflict affected society to how it was before or improve the previous creating a 'new normal'.

According to the World Bank (2000), combining indigenous entrepreneurial efforts and social entrepreneurship initiatives, sustainable development and reconstruction may be achieved in regions that have been shattered by war. Rebuilding of communities and their economies shattered by conflict is not an easy undertaking (Boudreaux \& O' Del 2004). Further, rebuilding such items as concepts of private property, social, legal and economic principles for economic development is important. Reconstruction involves complex and multifaceted processes including relief organizations' efforts (Labadie, 2008). In the South Eastern European regions depleted by conflict, an all-inclusive approach to rebuilding that incorporated economic development, micro and small enterprise growth including enhancement of social-political steadiness was inevitable, implemented by the World Bank (World Bank, 2000). Reconstruction in the Balkans involved development of infrastructure (roads, highways and railways), communications, power generation and social and economic structure of the societies. Initiating development programs for the purpose of improving people's incomes, therefore engaging them in productive activities to discourage the target group from participating in war is key (ITDG, 2004).

Where personal success is understood in terms of entrepreneurial resourcefulness instead of fighting proficiency, multinational institutions working with indigenous communities can help alleviate rampant conflict and poverty. Industrial development board of the (United Nations Industrial Development Organization (UNIDO), 2004) through a report by the Director General, indicated commitment to industrial rehabilitation and reconstruction 
in countries emerging from war. UNIDO's initiative was based on the continuum from relief to rehabilitation and development in post-crisis countries. In its post-crisis interventions, the emphasis was on the indigenous persons directly affected. In Afghanistan UNIDO aimed at promoting rehabilitation of industrial enterprises among rural communities. This was done through agricultural productivity and promotion of auxiliary income generating activities and community level self-help rural production activities for improved economic well-being of conflict affected population. PostAngola crisis program involved investment in non-oil sector and rural entrepreneurship development while industrial rehabilitation was initiated in Congo. Sierra Leone activities included entrepreneurship development and food security while community based, off grid rural power projects using renewable energy resources took effect in Rwanda.

Though there exist major challenges posed by globalization in terms of external knowledge and knowledge generated from within, local knowledge has been argued to be a strategic asset in strengthening people against isolation and promoting development especially after conflict. Indigenous entrepreneurship activities as post-conflict reconstructive mechanisms in Turkana County are not documented. Indigenous entrepreneurship is downplayed at the expense of relief aid while conflict 'management' perceived 'normal' has superseded the important role of post-conflict reconstruction. Activities have taken the approach of charity, mission and relief, exposing the people to neglect and marginalization. Promoting indigenous entrepreneurship will reduce multinational commercial rivalry in post-conflict zones (in search of contracts), ending the perception that they are only interested in commercial gains and therefore may agitate violence behind the scenes to 'create business' for themselves.

\section{Conceptual Framework}

The framework presented in Figure 1 shows the relationships between indigenous entrepreneurship, post-conflict reconstruction and their contribution to economic development configured out of the researchers' perception of study variable relationships supported by discussed literature. It illustrates indigenous entrepreneurship configured as independent variable, positively contributing to economic development configured as the dependent variable. Post-conflict reconstruction have strong contingent effects in the relationship between indigenous entrepreneurship and economic development. 
Figure 1: Conceptual Model

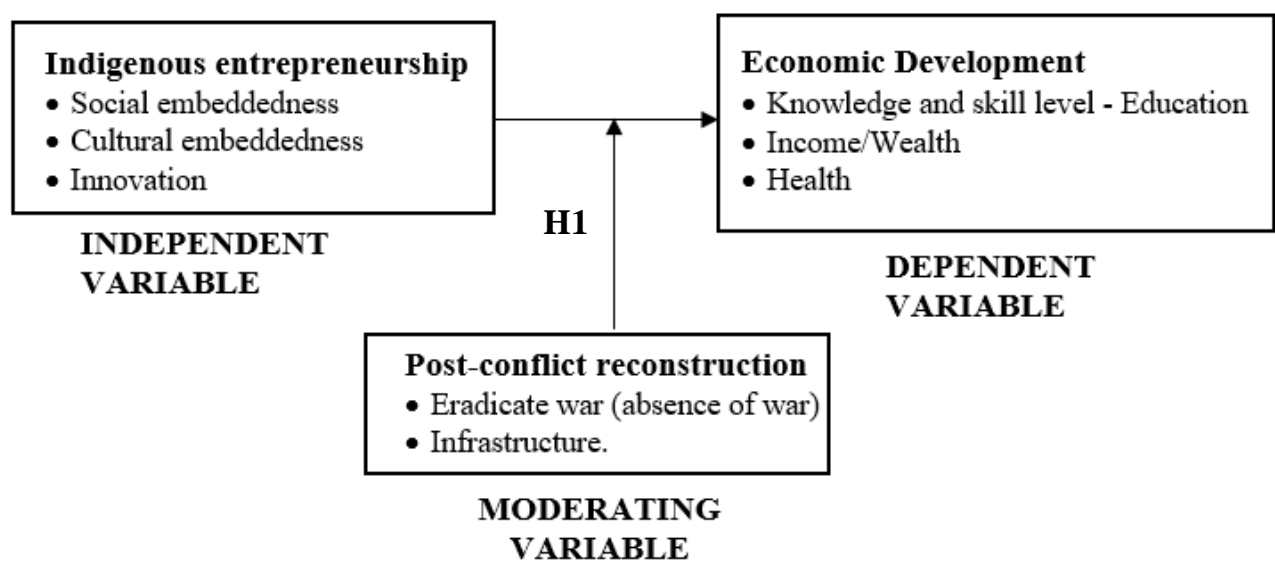

\section{Research Methodology}

This study adopts both positivism and phenomenology philosophical orientation (Swanson \& Holton, 2005). Positivism is a quantitative approach with a view that the social world is external and objectively observed. However, reality is subjective and multiple hence only understood by examining the perceptions of selected case studies combining quantitative and qualitative research in this study (Swanson \& Holton, 2005). The study adopts the cross-sectional design, which entails qualitative or quantitative data collection linking two or more variables amongst two or more cases at a single point in time, which are then examined to detect patterns of association (Bryman, 2004). Study population target was all micro and small livestock businesses, registered members of the Livestock Marketing Associations (LMAs), under the main umbrella of the County Livestock Marketing Council (CLMC) in Turkana County. A list comprising of 598 livestock enterprises availed from the CLMC as at December 2018 formed the population of this study. Proportionate stratified random sampling technique was used. The stratus were the four main livestock markets ITDG, (2005), that is Lokichoggio registering 67 MSEs, Kakuma had 56 MSEs, Lokichar 55 MSEs and Lodwar had 420 registered MSEs. Determining adequate sample size for each stratum amongst a population of 598 micro and small livestock businesses, this research adopted (Frankfort-Nachmias \& Nachmias, 1996) formula presented as follows:

$$
n^{1}=\frac{n}{1+\frac{n}{N}}
$$

Where $\mathrm{N}=$ size of population, $\mathrm{n}=$ estimated size of sample and $\mathrm{n}^{1}=$ optimal sample size. 
This formula was applied on the population to get 339 MSEs sample size with 38 MSEs from Lokichoggio, Kakuma had 32 MSEs, Lokichar had 31 MSEs and 238 MSEs from Lodwar. This study targeted the owners or senior managers of the 339 micro and small livestock businesses in the sample, as the point of inquiry for their good prospects to provide required and accurate information (Kumar 2005). The study purposely selected four firms from the survey method for case studies one each from Kakuma, Lokichoggio, Lokichar and Lodwar. Descriptive statistics were used to analyze basic information about the data.

Study variables were tested for linear relationships using Spearman's, correlation analysis. ANOVA, technique was conducted to test the significance of the model. Before testing the hypothesis, the study subjected the model to tests of statistical assumptions including normality, linearity, heteroscendasticity and multicollinearity. To test the hypothesis, simple and multiple linear regression model was computed. Statistical significance was tested at 0.05 level. Information obtained from the four case studies was analyzed by way of focus group discussions and thematic conceptual content analysis. The case study findings were compared (triangulation) with results from the survey data. Cronbach's alpha coefficient $\alpha$, was computed using Stata software to determine reliability of the research instrument where all variables used in modeling were tested.

Table 1: Reliability Test

\begin{tabular}{ccc}
\hline Variable & Number of items & Cronbach's alpha \\
\hline Indigenous Entrepreneurship & 22 & 0.9809 \\
Post-Conflict Reconstruction & 20 & 0.9924 \\
Economic Development & 11 & 0.9576 \\
\hline
\end{tabular}

Source: Primary Data

From Table 1, post-conflict reconstruction had the highest Coefficient of 0.9924 , followed by indigenous entrepreneurship with 0.9809 while economic development had the least Coefficient of 0.9576, values above 0.7 and therefore acceptable (Bryman \& Crammer,1997). To enhance the reliability of the questionnaire, a pilot study was conducted using random selection of $10 \%$ owners or senior firm managers and Cronbach's alpha coefficient $\alpha$, calculated to assess the device's consistency. Discriminant validity measured whether concepts that are purported to be unrelated are actually unrelated. The extent to which the research instrument is measuring the intended construct rather than an extraneous factor was measured by incorporating a panel of experts familiar with the constructs, to limit expert bias (Cooper \& Schindler, 2014). Panels of experts in post-conflict reconstruction and university academicians (economists and entrepreneurship), participated in discussions on research findings and 
recommendations to establish practical areas of interventions in policy and or implementation of suggestions to identified beneficiaries.

\section{Study Results}

The study sought to establish the moderating effect of post-conflict reconstruction, on the contribution of indigenous entrepreneurship among micro and small livestock enterprises to economic development in Turkana County. A total of 339 questionnaires were administered to the sampled respondents, out of which approximately 265 questionnaires were properly filled and returned representing an overall successful response rate of $78.17 \%$ (Babbie, 2015). Only 74 firms, that is 21.8 percent that did not respond to the questionnaires. The responses were evaluated using the 5-point Likert-type scale. The respondents were asked to indicate the extent of agreement with each of post-conflict reconstruction (PCR) statements, where (1. Not at all 2. Little extent 3. Moderate extent 4. Great extent 5. Very great extent). Absence of war and infrastructure were considered as the main factors explaining postconflict reconstruction (PCR), analyzed in order to determine the moderating effect of post-conflict reconstruction on the contribution of indigenous entrepreneurship among micro and small livestock enterprises to economic development in Turkana County.

From the results in Table 2, most of the respondents to a moderate extent agreed that absence of war had a great impact on post-conflict reconstruction. Majority of the respondents agreed to a great extent that traditional council of elders had been involved in managing and resolving conflicts (Mean=3.64, $\mathrm{SD}=1.06, \mathrm{CV}=29.12$ ) while international companies and agencies were agreed to a moderate extent, that they had contributed to peace in the region (Mean=3.22, $\mathrm{SD}=1.23, \mathrm{CV}=38.30)$. On the side of infrastructure, as indicated in Table 2, twelve (12) statements were objectively analyzed. Most of the respondents disagreed to a large extent that they used airstrips to export livestock products (Mean=2.19, $\mathrm{SD}=0.86 \& \mathrm{CV}=39.24)$. In addition, respondents agreed to a moderate extent that the use of communication technology contributed to income growth (Mean=3.48, $\mathrm{SD}=1.11, \mathrm{CV}=31.91)$.

Table 2: Post-conflict Reconstruction

\begin{tabular}{llllll}
\hline Post-conflict reconstruction & Mean & STD & CV & Skewness & Kurtosis \\
& Eradicate War (Absence of War) & & \\
$\begin{array}{l}\text { Our business have benefited from } \\
\text { conflict associated opportunities } \\
\text { related to reconstruction (e.g. }\end{array}$ & 3.3245 & 1.1080 & & -0.2304 & 2.3299
\end{tabular}


Traditional council of elders have been involved in managing and resolving conflicts

Inter-community dialogues, peace meetings, trauma healing sessions and compensation schemes are practiced to initiate peace The national government initiatives through the offices of chiefs, District Officers and County Commissioners have been effective in resolving disputes

The African Union, Nepad, IGAD and the East African Community have established peace and security initiatives in Africa International companies and agencies have contributed to peace in the region

$3.4377 \quad 1.1335$
$3.6415 \quad 1.0606$

$3.6415-1.0606$

$-0.2441$

2.2622

32.9737
$3.3245 \quad 1.1216$
$-0.2270$
2.2605

33.7362

$3.3170 \quad 1.0433$

$-0.1795$

2.3559

31.4542

$\begin{array}{llll}3.2189 & 1.2329 & -0.1909 & 1.9887\end{array}$

\begin{tabular}{llllll} 
& \multicolumn{7}{c}{38.3030} \\
\hline Average & $\mathbf{3 . 3 7 7 4}$ & $\mathbf{1 . 1 1 6 7}$ & $\mathbf{3 3 . 0 6 2 9}$ & $\mathbf{- 0 . 2 1 8 7}$ & $\mathbf{2 . 2 4 5 6}$ \\
\hline
\end{tabular}

\section{Infrastructure}

Our business has benefited from research institutions and centres in terms of technological innovations Our business benefits from livestock business incubator

Our business is located close to tarmac roads

We transport our livestock from the source via murram roads

We use airstrips to export livestock products

The Livestock Marketing

Association use electricity to run their day to day operations for example lighting

A functional health facility (clinic,

dispensary or hospital) is close to my

home

There is a functional primary school near my home

We hold meetings of various

livestock marketing associations in

the public social hall(s) close to our business

The employees of this firm have adopted the use of mobile phones,

$3.3660 \quad 1.1862$

$-0.2045$

2.1339

35.2416

$\begin{array}{lllll}3.3019 & 1.1313 & 34.2608 & -0.1868 & 2.1943 \\ 3.3623 & 1.0927 & 32.4994 & -0.2303 & 2.3575 \\ 3.2151 & 1.1159 & 34.7081 & -0.1195 & 2.2040 \\ 2.1962 & 0.8619 & 39.2435 & 0.0213 & 2.0868 \\ & & & & \\ 3.4604 & 1.0110 & & -0.1342 & 2.3229\end{array}$

29.2162

$3.3019 \quad 1.1007$

33.3356

$-0.2076$

2.2769

$3.4264 \quad 1.1228$

32.7687

$-0.2501$

2.2974

$2.9019 \quad 1.1103$

38.2612

0.0445

2.2004

$3.1623 \quad 1.2155$

$-0.1860$

2.0632 
computers and the internet technology in enterprise transactions Use of communication technology contributes to income growth

$3.4830 \quad 1.1115$

For internal business operations we have adopted electronic automation such as e-marketing

Our business is adopting the use of social media and electronic platforms (either Organization's website and email, SMS Services/ WhatsApp/Instagram, Twitter, Facebook or LinkedIn) to increase sales and income Our business embraces continuous training and learning on new communication technology for the staff to effectively use
3.3132
1.1231

$3.2604 \quad 1.1198$
$-0.1683$

2.1812

$$
-0.2225 \quad 2.3626
$$

$-0.2037$

$$
33.8980
$$
3.3849
1.1327
$-0.2305$
2.2516

33.4645

\begin{tabular}{lllll}
3.2811 & $\mathbf{1 . 1 2 5 0}$ & $\mathbf{3 4 . 2 8 5 5}$ & $\mathbf{- 0 . 1 6 2 7}$ & $\mathbf{2 . 2 2 7 0}$ \\
\hline
\end{tabular}

Source: Primary Data

The moderating effect is measured by establishing change on the relationship between the independent variable and dependent variable after the introduction of the moderator. The objective was achieved by testing the following hypothesis.

$H_{1}$ : Post-conflict reconstruction has no moderating influence on the relationship between indigenous entrepreneurship among micro and small livestock enterprises and economic development in Turkana County.

Simple and multiple regression analysis proposed by Baron and Kenny (1986) was conducted to test the moderating effect.

\begin{tabular}{|c|c|c|c|c|c|}
\hline \multicolumn{6}{|c|}{ Model Summary } \\
\hline & Model & $\mathrm{R}$ & $\begin{array}{c}\mathrm{R} \\
\text { Square }\end{array}$ & $\begin{array}{l}\text { Adjusted R } \\
\text { Square }\end{array}$ & Std. Error of the Estimate \\
\hline 1 & $\begin{array}{l}\text { Indigenous } \\
\text { entrepreneurship }\end{array}$ & .884 & .771 & .715 & 0.0687 \\
\hline 2 & $\begin{array}{l}\text { Indigenous } \\
\text { entrepreneurship, Post- } \\
\text { conflict reconstruction }\end{array}$ & .979 & .976 & .835 & 0.0581 \\
\hline
\end{tabular}

Table 3: Regression Results for Post-Conflict Reconstruction, Indigenous Entrepreneurship and Economic Development

Analysis of Variance (ANOVA)

\begin{tabular}{lllccccc}
\hline \multirow{2}{*}{ Model } & & $\begin{array}{c}\text { Sum of } \\
\text { Squares }\end{array}$ & df & Mean Square & F & Sig. \\
\hline \multirow{2}{*}{1} & $\begin{array}{l}\text { Indigenous } \\
\text { entrepreneurship }\end{array}$ & Regression & 423.12 & 1 & 423.12 & 129.39 & .000 \\
\cline { 2 - 9 } & Residual & 862.02 & 264 & 3.27 & & \\
\cline { 2 - 9 } & Total & 1285.14 & 265 & & & \\
\hline
\end{tabular}




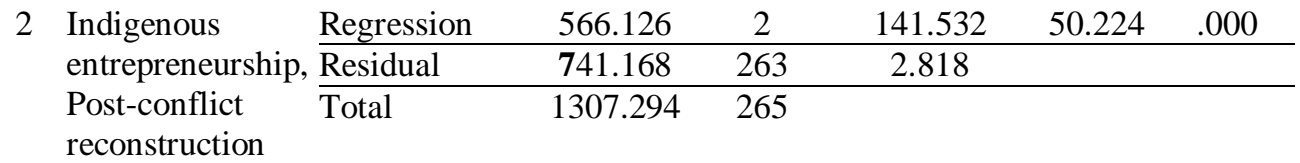

\begin{tabular}{|c|c|c|c|c|c|c|}
\hline \multicolumn{7}{|c|}{ Regression Coefficients } \\
\hline \multicolumn{7}{|c|}{ b. coefficients } \\
\hline & \multirow[t]{2}{*}{ Model } & \multicolumn{2}{|c|}{ Unstandardized coefficients } & $\begin{array}{c}\text { Standardized } \\
\text { coefficients }\end{array}$ & \multirow[b]{2}{*}{ t-stat } & \multirow[b]{2}{*}{ Sig. } \\
\hline & & B & Std. Error & Beta & & \\
\hline \multirow[t]{2}{*}{1} & (Constant) & .314 & .157 & & 2.00 & .036 \\
\hline & $\begin{array}{l}\text { Indigenous } \\
\text { entrepreneurship }\end{array}$ & .865 & .064 & $.689 *$ & 13.56 & .000 \\
\hline \multirow[t]{3}{*}{2} & (Constant) & .411 & .136 & & 3.022 & .000 \\
\hline & $\begin{array}{l}\text { Indigenous } \\
\text { entrepreneurship }\end{array}$ & .524 & .114 & $.453 *$ & 4.58 & .000 \\
\hline & $\begin{array}{l}\text { Post-conflict } \\
\text { reconstruction }\end{array}$ & .487 & .107 & $.449^{*}$ & 4.55 & .000 \\
\hline
\end{tabular}

Model 1 Predictor: (Constant) Indigenous entrepreneurship

Model 2 Predictors: (Constant) Indigenous entrepreneurship and Post-conflict reconstruction Dependent variable: Economic development

**Significance level of 5 percent

Source: Primary Data

In the first model (model 1) presented in Table 3, indigenous entrepreneurship was regressed on economic development. The model had an $\left(\mathrm{R}^{2}\right)$ of 0.771 , which implied that $77.1 \%$ of the variations in economic development are explained by changes in indigenous entrepreneurship. The study thus concludes that estimation of the proposed model could proceed and that estimates are not biased. The study established the regression model had a significance level of $0.00 \%$ indicating that the model was significant $(\mathrm{P}<0.05)$. Holding indigenous entrepreneurship constant, economic development increases by 0.314 units. In particular, the result showed that for a unit rise in indigenous entrepreneurship, economic development increased significantly by 0.689 units holding post-conflict reconstruction constant.

In the second model (model 2) as shown in Table 3, coefficient of determination was used to evaluate the model fit. The adjusted $R^{2}$, is the percent of the variance in the dependent explained uniquely or jointly by the independent variables. Results reveal that indigenous entrepreneurship and Post-conflict reconstruction significantly explained economic development. This is based on the value for coefficient of determination, which was 0.976 and adjusted to 0.835 . Both predictors thus explained $97.6 \%$ of their variation in economic development. This implies that indigenous entrepreneurship and post-conflict reconstruction have a strong relationship with economic development. From the fit statistics, the study concluded that estimation of the multiple linear regression model could proceed and that estimates were not 
biased. The study established the regression model had a significance level of $0.00 \%$, which is an indication that the data was ideal for making a conclusion on the population parameters, as the value of significance (p-value) was less than $5 \%$ indicating that the model was significant. The calculated value was greater than the critical value $(\mathrm{F}=50.224$, $\mathrm{p}$ value $=0.000)$ an indication that post-conflict reconstruction has a significant effect on economic development.

The composite index of the Post-conflict reconstruction dimensions and economic development was computed and a multiple regression analysis performed to establish the influence of Post-conflict reconstruction. The findings reveal that indigenous entrepreneurship and Post-conflict reconstruction significantly influenced economic development. From the fit statistics, the study concluded that estimation of the multiple regression model could proceed and that estimates were not biased. From the results, indigenous entrepreneurship and economic development, as well as Post-conflict reconstruction and economic development both were found to have a positive relationship. Holding indigenous entrepreneurship and post-conflict reconstruction constant, economic development increases by 0.411 units. The findings revealed that a unit rise in indigenous entrepreneurship led to an increase in economic development significantly by 0.453 units holding other factors constant. On the other hand, a unit increase in post-conflict reconstruction led to a significant rise in economic development by 0.449 units holding other factors constant. The following was the estimated and significant model;

$$
E D=0.411+0.453 I E+0.449 P C R
$$

The above model shows the extent to which significant factors affect economic development in Turkana County. From the p-value, the result implies that the null hypothesis of no significant effect is rejected. Since the coefficients in stated equation reduced from 0.689 to 0.453 , allows the researcher to conclude that Post-conflict reconstruction is a significant moderating variable between indigenous entrepreneurship and economic development. This means that absence of war and infrastructure strengthens the relationship between indigenous entrepreneurship and economic development. Significance however never changed but maintained to be highly significant. The null hypothesis of no significant moderating effect is thus rejected. However, some studies argue that such effect is weak as two out of the three main considerations are not affected hence the moderator is weak.

\section{Discussion of Results}

The moderating effect of post-conflict reconstruction on the relationship between indigenous entrepreneurship among micro and small livestock enterprises and economic development in Turkana County was supported. This is because the null hypothesis was rejected. This suggests that 
micro and small livestock enterprises depend on post-conflict reconstruction as a significant moderator on the relationship between indigenous entrepreneurship and economic development. The implication is that postconflict reconstruction indirectly contributes to economic development, through enhancing entrepreneurship which acts as a stimulus to struggling economies and thus seen as a tool for rebuilding of the economy and stimulation of the private sector. In the South Eastern European regions depleted by conflict, an all-inclusive approach to rebuilding that incorporated economic development, micro and small enterprise growth including enhancement of social-political steadiness was inevitable, implemented by the World Bank (World Bank, 2000).

Based on the quantitative analysis, post-conflict reconstruction had a significant moderating effect on the relationship between indigenous entrepreneurship and economic development. On the other hand the findings from the qualitative analysis (case studies) concur the same, for example one of the key informants interviewed argued that "we thank IOM for this initiative (non-violent migrations). Our school going children will grow up better informed about the ills of war and human trafficking and instead they will concentrate on their studies." Mieebo Livestock traders (case discussed), supported peace programs initiated by Turkana County government and Peace III in achieving peace both internal and cross border, with a view of achieving conducive environment for economic development. Joint cooperation of the government of Kenya, Turkana County, non-governmental organizations and donors had initiated various peace building and conflict management programs, which had positively impacted the operations of Mieebo Livestock traders and other businesses. Similarly, Nangorok livestock enterprise through PAX, antagonistic communities had been brought together along Kenya, Ethiopia, South Sudan and Uganda borders using dialogue to end hostility enhancing local and regional peace building. According to the World Bank, (2003) sustainable development requires coordination by foreign direct investors, communities and aid agencies.

\section{Conclusion}

This study is premised on the fact that post-conflict reconstruction attracts local, national, regional and international interventions. However, the link between reconstruction efforts and economic development trends had not been sufficiently thought through. 339 questionnaires were administered to the sampled respondents, out of which 265 firms $(78.17 \%)$ questionnaires were properly filled and returned. The relationship established based on the hypothesis, reveal that post-conflict reconstruction was found to have significant moderating effect on the relationship between indigenous entrepreneurship and economic development. Institutions created by post- 
conflict reconstruction activities for example legal system, therefore influence the contribution of indigenous entrepreneurship to economic development. The study concludes therefore that indigenous entrepreneurship is important in determining economic development, but not statistically important in influencing the same in presence of post-conflict reconstruction. Secondly the study concluded that eradication of war (absence of war), and infrastructure under post-conflict reconstruction influence the extent of effect significantly. Post-conflict reconstruction interaction term which defines moderation was statistically significant, thus confirming it as a moderator influencing economic development. The study concluded that indigenous entrepreneurship and post-conflict reconstruction with their respective indicators, were jointly significant in influencing economic development in Turkana County. Model fitness tested through $\mathrm{R}$ squared, revealed that postconflict reconstruction individually highly explained economic development.

This study confirms what other past studies have confirmed that micro and small livestock enterprises in Turkana County are vibrant contributors to the local economy, and in a similar manner could contribute to growth in other counties within Kenya and ultimately at national level. They are vital to postconflict reconstruction. The study was anchored on institutional theory. The implication of this study is its contribution to knowledge by empirically establishing that post-conflict reconstruction influences economic development, demonstrating that it is not only indigenous entrepreneurship that influences economic development. Under institutional theory, either regulatory, social and/ or cultural influences are seen as drivers for survival and legitimacy of an organization, promoting its success rather than focusing on organizational micro factors. Post-conflict reconstruction brings to play the contributions of aid agencies, multinational institutions and NGOs, communities and governments working in partnership with local leaders and organizations hence, establishing a consensus on what is needed to fulfill the host county's economic potential after war. Indigenous entrepreneurs through their social embeddedness, cultural embeddedness and innovativeness features, are expected to take entrepreneurial action through identifying local gaps where the demand for a product/service exceeds supply, therefore identifying an opportunity and validating its worth for exploitation

However, this is not the case based on the findings obtained in this study, which revealed that post-conflict reconstruction moderated the relationship between indigenous entrepreneurship and economic development in Turkana County. The study supports institutional theory, which ultimately argues that formal institutional structures are necessary for venture creation while "too many rules and procedural requirements" discourage entrepreneurs from venturing. This is regardless of the argument that regulatory, social and cultural influences promote survival and legitimacy of an organization, 
promoting its success rather than focusing on organizational micro factors. Entrepreneurial process involves the individual, environment, organisation and that personality and motivational drives begins to develop very early with the family, friends, society and schools. The findings are in line with progressive collaborations where indigenous effort and entrepreneurial development are combined with social entrepreneurship initiatives leading to sustainable development especially in regions that have their economies shattered by war.

\section{Recommendations}

The study should aid both the national and County governments in the legislation of laws and policies which support micro and small livestock enterprises in Turkana County, for instance, creation of a suitable environment for these businesses to obtain credit and recommending suitable and efficient trading activities. Based on the findings, the study also agrees that the causes of conflict revolves on core resources, political economy, infrastructure and insecurity. The study suggests that national government should enhance state approaches in collaboration with the County government of Turkana in order to eradicate the conflict effectively, prohibiting acquisition of small arms. In post-conflict environments MSEs' are resource constrained and this study suggests that policy makers initiate programs aimed at supporting indigenous entrepreneurs deal with negative effects associated with conflict. The County government of Turkana is supposed to have a paradigm shift to institutionalize indigenous entrepreneurship to foster self- regeneration and economic development. The study thus suggest for the county government of Turkana to refocus on the decentralization policy perhaps integrate with indigenous entrepreneurship so that it can induce economic activity from outside business players. Actually, the study supports other policy implications that its time both levels of governments enhance their environmental factors to lower uncertainty, raise indigenous entrepreneurs to participate at the global economy, attracting FDI, private sector development, employment, increased exports and finally spur economic development through huge investments in health, education while impacting wealth levels.

\section{Suggestions for Further Research}

The study limited its scope to Turkana County and excluded other micro and small livestock enterprises in other Counties such as Samburu, Wajir, Garissa or even Marsabit within Kenya, which exhibit similar operational characteristics. The fact of limiting the study to one geographic area limits the possibility of a larger population and equally limits the sample size, which in this case was limited to Turkana County. The contextual limitation therefore restricts the generalization of the study findings to the 
micro and small enterprises operating within the livestock sub sector in Turkana County. A cross-sectional survey design was used for this study while assessing economic development. However, as it is known, cross- sectional studies do not capture causal effects of variables. Future research could use a longitudinal study stretching several years on a sample number of firms. This will better explain the effects of the variables on economic development such as which enterprise performed better or worse.

\section{References:}

1. Aldairany, S., Omar, R. \& Quoquab, F. (2018). Systematic review: Entrepreneurship in conflict and post conflict. Journal of Entrepreneurship in Emerging Economies, https://doi.org/10.1108/JEEE-06-2017-0042

2. Audretsch, A. D., \& Kelibach, M. (2008). Resolving the knowledge paradox: Knowledge -spill over entrepreneurship and economic growth. Research Policy, 37(10), 1697-1705.

3. Babbie, E. R., (2015). The practice of social research (12 th $\mathrm{Ed}$.). Belmont, CA: Wadsworth, Cengage Learning.

4. Baker, T. A., \& Nelson, R. E. (2005). Creating something from nothng: Resource construction through enterpreneurial bricolage. Administrative Science Quartely, 50, 329-366.

5. Boudreaux, J., \& O'del, J. (2004). Complexities of entrepreneurship/economic development in war torn societies: Implications for international entrepreneurship education efforts. Retrieved from

http://usasbe.org/knowledge/proceedingsDocs/UASBE2004proceedin gs-Odel.pdf

6. Bray, J. (2005). International companies and post-conflict reconstruction: Cross-sectoral comparisons. Social development papers; conflict prevention and reconstruction paper No. 22. Retrieved from http://www.worldbank.org/conflict

7. Bruton, G. D., Ahlstrom, D., \& Han-Lin Li (2010). Institutional theory and entrepreneurship: Where are we now and where do we need to move in the future? Entrepreneurship Theory and Practice, 34 (3), 421-440

8. Bryman, A. (2004). Social research methods (2 $2^{\text {nd }}$ Ed.). Oxford University Press, NY.

9. Bryman, A., \& Cramer, D. (1997). Quantitative data analysis with SPSS for windows: A guide for Social Scientists. London, Routledge.

10. Cooper, D. R., \& Schindler, P. S. (2014). Business research methods (12 ${ }^{\text {th }}$ Ed.). New York, NY: McGraw-Hill Education 
11. Das, K. K., \& Quirk, T. (2016). A review of the recent literature on institutional economics analysis of the long-run performance of nations. Asian-Pacific Economic Literature, 28: 178-186.

12. Department For International Development- DFID. (1999). Understanding and managing pastoral conflict in Kenya: A literature review. Retrieved from

http://citeseerx.ist.psu.edu/viewdoc/.download?doi=10.1.1.505.7930 \&rep $=1 \&$ type $=$ pdf

13. Devine, P. R. (2016). Persistent conflict between the Pokot and the Turkana: Causes and policy implications. (Unpublished PhD Thesis) Nairobi: University of Nairobi, Department of Political Science and Public Administration.

14. DiMaggio, P. J. \& Powell, W. W. (1983). The iron cage revisited: Institutional isomorphism and collective rationality in organizational fields. American Sociological Review, 48 (2), 147-160.

15. DiMaggio, P. J. \& Powell, W. W. (1991). The new institutionalism in organizational analysis. Chicago, University of Chicago Press

16. Frankfort-Nachmias, C., \& Nachmias, D. (1996). Research methods in the social sciences ( $5^{\text {th }}$ Ed.). London, Great Britain: St Martins Press.

17. Government of Kenya (2010). Agricultural sector development strategy, 2010-2020. Retrieved from

http://www.finland.or.ke/public/.download.aspx?ID=107015\&GUID =\%7BCE7EA0C9-18D4-41ED-B169-5AE7DAD3B6B5\%7D.

18. Government of Kenya (2012). The Micro and Small Enterprise Act, 2012: Government Press.

19. Green, R. (1995). Widening horizons in post-war reconstruction: Prevention and management. An International Journal, 4(1), 38-44.

20. Intermediate Technology Development Group- ITDG. (2005). Livestock Market Acess Initiative: Pre-assessessment and feasibility analysis, North Eastern Turkana. Nairobi, Kenya: Intermediate Technology Development Group - East Africa.

21. Knowles, S. (2007). Is Social Capital Part of the Institutions Continuum and is it a Deep Determinant of Development? In G. Mavrotas \& A. Shorrocks, (Eds.), Advancing development: Core themes in global economics, (pp. 197-227). New York, N.Y: Palgrave Macmillan.

22. Kumar, R. (2005). Research methodology: A step-by-step guide for beginners ( $2^{\text {nd }}$ Ed.). Singapore: Pearson Education.

23. Labadie, J. R. (2008) Auditing of post-disaster recovery and reconstruction activities: Disaster prevention and management. An International Journal, 17 (5), 575-586. 
24. Lingelbach, D., Lynda, V., \& Asel, P. (2005). What's distinctive about growth-oriented entrepreneurship in developing countries? SSRN Electronic Journal, 10.2139/ssrn.742605.

25. Luiz, J. M. (2010). Economic perspectives of entrepreneurship. In B. Urban, (Ed.), Frontiers in Entrepreneurship, (pp. 63-84). Berlin, Germany: Springer-Verlag. Doi:10.1007/978-3-642-04502-8.

26. Meyer, J. W. \& Rowan, B. (1977). Institutionalized organizations: Formal structure as myth and ceremony. American Journal of Sociology, 83 (2), 340-363.

27. Naude, W. (2008). Entrepreneurship in economic development: Research Paper No.2008/20. Retrieved from https://pdfs.semanticscholar.org/83dc/0215aba844381f2ee825490513 9abcfaba97.pdf

28. Naude, W. (2013). Entrepreneurship and economic development: Theory, evidence and policy. Discussion Paper No.7507. Retrieved from http://ftp.iza.org/dp7507.pdf

29. North, D. C. (1990). Institutions, institutional change and economic performance. Cambridge, CA: Cambridge University Press.

30. Oyugi, W. O. (2002). Politicized ethnic conflict in Kenya: A periodic phenomenon. Addis Ababa, Ethiopia.

31. Ruto, P., Mohamud, A., \& Masinde, I. (2006). Indigenous democracy: Traditional conflict resolution mechanisms. The case of Pokot, Turkana, Samburu and Marakwet communities. ITDG, Nairobi.

32. Skran, C. (2020). Refugee entrepreneurship and self-reliance: The UNHCR and sustainability in post-conflict Sierra Leone. Journal of Refugee Studies, 33 (1), 268-298.

33. Swanson, R. A., \& Holton, III E. F. (Eds.). (2005). Research in organizations: Foundations and methods of inquiry. San Francisco, CA: Berrett-Koehler

34. Tobias, J., \& Boudreaux, K. (2009). The role of entrepreneurship in conflict reduction in the post-genocide Rwandan coffee industry: Quantitative evidence from a field study. Journal of small business and entrepreneurship, Mercatus Center; George Mason University, Working Paper 1-28.

35. Todaro, M. P., \& Smith, S. C. (2012). Economic development $\left(11^{\text {th }}\right.$ Ed.). Addison-Wesley, Boston: Pearson Education.

36. Tsilika, T., Kakouris, A., Apostolopoulos, N., \& Dermatis, Z. (2020). Entrepreneurial bricolage in the aftermath of a shock. Insights from Greek SMEs. Journal of Small Business \& Entrepreneurship, DOI: 10.1080/08276331.2020.1764733

37. United Nations Industrial Development Organization. (2004). UNIDO activities in Countries emerging from crisis situation. Retrieved from 
https://www.unido.org/sites/default/files/.2007-

11/28006_idb29_11e_0.pdf

38. Welfens, P. J. J. (2013). Theoretical aspects of globalization: Economic growth \& social security: Social security and economic globalization, pp 85-111 DOI10.1007/978-3-362-408809_3,

39. Williams, N. (2019). Moving beyond financial remittances: The evolution of diaspora policy in post-conflict economies. International Small Business Journal: Researching Entrepreneurship, DOI:10.1177/0266242619878064.

40. World Bank, (2000). The road to stability and prosperity in South Eastern Europe: A regional strategy paper. Retrieved from http://www/seerecon.org/Regional\%20Initiatives/WBRegionaltrategy /chapter4.htmInitiatives/WBRegionalStrategy/chapter5.htm

41. World Bank, (2003). Rebuilding the Balkans. Retrieved from http://web.worldbank.org/WBSITE/EXTERNAL/NEWS/O,,content MDK:20091875menup 